\title{
The measures for achieving nZEB standard of retrofitted educational building for specific polish location - case study
}

\author{
Jerzy Kwiatkowski ${ }^{1,}$, Maciej Mijakowski ${ }^{1}$, and Adrian Trząski ${ }^{1}$ \\ ${ }^{1}$ Warsaw University of Technology, Faculty of Building Services, Hydro and Environmental \\ Engineering, ul. Nowowiejska 20, 00-653 Warszawa, Poland
}

\begin{abstract}
Most of the EU member states have already set a definition of nZEB for new buildings and some of the countries also done it for existing buildings. As there is no definition of nZEB for existing buildings in Poland, the paper will include various considerations of such a standard. Next, a case study of educational building retrofitting to a proposed nZEB standard will be presented. The aim of the paper is to present what measures can be used in order to decrease energy consumption in existing building. The measures are divided into three parts: architectural and construction, installations and energy sources. Thus a complexity of the solutions are presented. As the nZEB standard is related to available energy sources, also an influence of local condition will be considered. Building chosen for analysis is located in an area under historic protection which makes the work even more difficult. It was proved that used solutions were chosen not only to reduce energy demand or increase energy production from renewable energy sources, but also to increase social and aesthetic features of the building.
\end{abstract}

\section{Introduction}

The Recast of the Directive on the Energy Performance of Buildings (the EPB Directive) [1] came into force on 9 June 2010. EU member states should until 9 June 2012, publish the relevant laws and administrative regulations necessary to implement its provisions. European regulatory efforts towards increasing energy efficiency of buildings are focusing on building requirements. All new public building after 31.12.2018 must be nearly zero energy buildings. Such requirement can be very hard to implement in public buildings as the energy needs for heating, cooling and lighting to provide internal comfort are typically very high. It is even harder to retrofit existing public buildings to nearly zero energy standard. In this paper an integrated energy design (IED) process in public building retrofitted to nZEB standard will be presented. In the first step a definition of nZEB standard is given, next an integrated energy design (IED) process is shortly described and in the last part an example of use of IED in educational building retrofitting process is given.

\footnotetext{
${ }^{*}$ Corresponding author: jerzy.kwiatkowski@is.pw.edu.pl
} 


\section{2 nZEB definition}

Directive 31/2010/EU [1] requires the introduction of nearly zero-energy buildings but does not specify a minimum or maximum harmonized requirements and detailed guidance framework procedure for calculating the energy performance of building. Member states have to define what that means exactly for them. Taking into account the local conditions in the definition does not preclude the adoption of a uniform methodology in all Member States.

The Directive defines a nearly zero-energy building as a high energy performance building and requires the determination of the ratio of primary energy. Very low or almost zero energy demand of the building should be covered from renewable energy sources or renewable sources produced on-site.

In Poland a nZEB standard has been defined by primary energy indicator (EP) and set in Ordinance on technical conditions to be met by buildings and their location [2]. For public buildings, like educational building maximal value of EP has been state as sum of three indicators:

- for heating and domestic hot water $-45 \mathrm{kWh} / \mathrm{m}^{2} \mathrm{a}$;

- for cooling - $25^{*}\left(\mathrm{~A}_{\mathrm{f}, \mathrm{c}} / \mathrm{A}_{\mathrm{f}}\right) \mathrm{kWh} / \mathrm{m}^{2} \mathrm{a}$ (where $\mathrm{A}_{\mathrm{f}, \mathrm{c}}$ is a cooled area and $\mathrm{A}_{\mathrm{f}}$ is a total regulated temperature area);

- for lighting - $25 \mathrm{kWh} / \mathrm{m}^{2} \mathrm{a}$ for time of light operation $<2500 \mathrm{~h} /$ year and $50 \mathrm{kWh} / \mathrm{m}^{2} \mathrm{a}$ for time of light operation $\geq 2500 \mathrm{~h} /$ year.

In total maximum EP may vary from 70 to $120 \mathrm{kWh} / \mathrm{m}^{2} \mathrm{a}$.

From the other hand in a Directive $31 / 2010 / \mathrm{EU}$ a requirement of cost optimal parameters is given. Hence in the KODnZEB project [3] a study of the cost optimal EP value for educational building estimation has been done. The calculation has shown that cost optimal EP indicator should have value between 40 and $55 \mathrm{kWh} / \mathrm{m}^{2} \mathrm{a}$ [4].

Despite existing requirements or analysis for the use of KODnZEB project a value of primary energy indicator equal to $20 \mathrm{kWh} / \mathrm{m}^{2}$ a has been set as nZEB standard for two chosen buildings. Such a stringent requirement was defined as a goal was to prove that educational building can be retrofitted with very high energy requirement reduction.

\section{Retrofitting measures}

An energy needs of the buildings are sum of a heat needs for heating and hot water preparation, cool needs for cooling and electricity for lighting and technical systems (pumps, vents). In complex retrofitting a modernization of each energy needs has to be taken into consideration.

An energy consumption for heating depends on thermal quality of envelopes (external walls, roofs or floors on the ground), windows and ventilation system (natural, mechanical, with or without heat recovery). In order to decrease energy needs for heating an additional layer of insulation material on walls or roofs or replacement of windows can be proposed. It is also required to use controlled ventilation with heat recovery.

The heat needs for hot water preparation are related with consumption. The best solution in reducing such needs is use of water efficient taps.

In the lighting system two main measures can be proposed: replacement non-efficient lighting bulbs to LED installation and use of control system (occupancy sensor, zoning).

For the technical system consumption an energy efficient pumps and vents with inverter can be proposed. It is also recommended to design low pressure ventilation system in case of mechanical ventilation with heat recovery. 


\section{Case building description}

In the KODnZEB project two building were chosen in order to verify possibility of retrofitting them to nZEB standard. One of the buildings is educational building constructed in 1970. Building is located in Warsaw (Poland) in highly urbanized area. The building location with its surroundings is presented in Fig. 1.
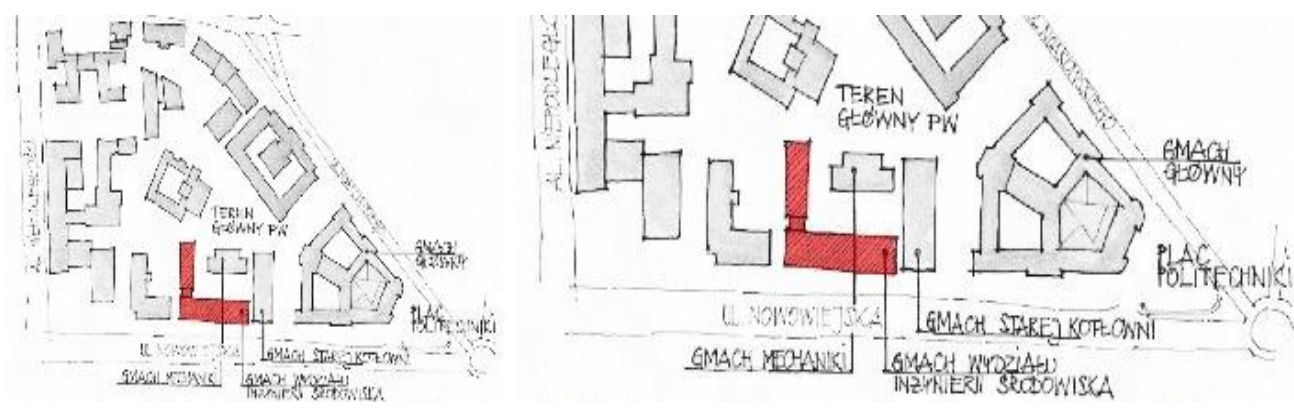

Fig. 1. Location of analysed building on the Warsaw University of Technology campus (marked with red).

The south façade of the building is oriented to the street and city tram line. Thus beside the overheating problem during spring and autumn (July and August are free of classes) the outside noise are reason of uncomfortable environment in the internal spaces. The others façades of the building are oriented to Warsaw University of Technology internal campus so the outside noise is not a problem. Some overheating occurs in the spaces oriented to the west.

The building has two wings: lower with 8 over ground levels and higher with 11 over ground levels. A total heated area of the building is equal to $18850 \mathrm{~m}^{2}$. A variety of different function of spaces can be identified within the building: lecture rooms, auditoria, chemical and biological laboratories, mechanical laboratories, computer laboratories, offices and corridors and sanitary units. In the Fig. 2 a layout of the example floor is presented.

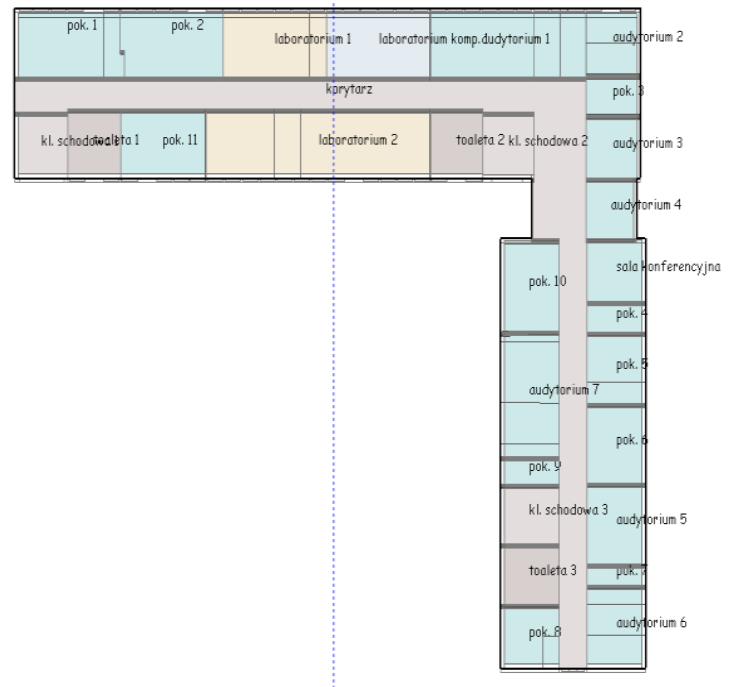

Fig. 2. A layout of second floor of the building. 
It can be noticed that different spaces are mix with each other and it is no possible to divide building into functional spaces. A such variety of functions makes the retrofitting of this building very complex, as in each space different occupancy, lighting or internal gain scheduled occurs.

The insolation of the building do not fulfil current building regulation in Poland. Also natural ventilation and low quality lighting system are the reason of low building energy characteristic. Thus some measures are required for decrease energy needs and to achieve nZEB standard.

As it was described earlier definition of nZEB standard is based on primary energy. Thus a primary resource factor (PRF) of energy source will have a huge influence on final results. This building is supplied in electricity from central electricity network with the $\mathrm{PRF}_{\mathrm{el}}=3.00$, and from photovoltaic system with $\mathrm{PRF}_{\mathrm{PV}}=0.00$. The heat is supplied for district heating network with $\mathrm{PRF}_{\mathrm{DH}}=0.68$. It must be added that in Poland a primary resource factor for fossil fuels like coal, oil or gas is equal to 1.00. Thus a use of district heating as heat source is reasonable. Also the PRF value for the electricity shows that use of compressor heat pump for heating can increase primary energy in comparison with district heating.

\subsection{Energy standard of existing building}

Energy simulations are carried out in the program for the comprehensive thermal analysis of buildings DesignBuilder [5]. The software is compatible with the guidelines CIBSE AM11 "Building energy and environmental modelling". DesignBuilder uses the latest Energy Plus simulation engine for energy calculation. Energy Plus is the U.S. DOE building energy simulation program for modelling building heating, cooling, lighting, ventilating, and other energy flows.

In the program a numerical 3D model of the building can be created. Next each envelope is described by heat transfer coefficient and for windows also total solar transmission and light transmission. For defined zones following data can be set: occupancy, internal loads, light quality, ventilation rates, HVAC systems and usage schedules of each parameter. In the last stage the weather data are set. This detailed building model allows the calculation of the energy consumption for heating, cooling and artificial lighting.

In the table 1 an energy characteristic of the existing building has been showed.

Table 1. The energy characteristic of the existing building.

\begin{tabular}{|c|c|}
\hline \multicolumn{2}{|c|}{ EP indicator $\left[\mathbf{k W h} / \mathbf{m}^{\mathbf{2}} \mathbf{a}\right]$} \\
\hline Heating and ventilation & 72.2 \\
\hline Domestic hot water & 8.8 \\
\hline Cooling & 0.9 \\
\hline Lighting & 60.6 \\
\hline Auxiliary energy & 12.8 \\
\hline PV installation & -6.5 \\
\hline Sum & 148.9 \\
\hline
\end{tabular}

It can be noticed that highest energy needs are for heating and ventilation and for lighting. Therefore the main goal school be decrease consumption in this area. 


\subsection{Retrofitting measures}

As it can be noticed the main energy needs are related with space heating. Therefore the first idea was to add extra insulation on the walls and roofs and replace existing windows to ones with lower U value. Such measures will result in decreasing of transmission heat loses.

The other high energy consumption in connected with ventilation system. Thus a mechanical ventilation with heat recovery was considered. However the occupancy of spaces within a building is different and centralized ventilation could work not properly. In addition the building is on constant operation any measure that needs construction work inside a building should not be applied. Thus a decentralized ventilation with heat recovery was proposed. A individual ventilation unit will be placed in each of room. But Polish regulation forbidden and inlet and exhaust of ventilation air to be close to each other. Such situation would occur in this case. It was then proposed to use individual inlet for each ventilation unit and common exhaust duct installed on the outside façade.

The increase of the thermal properties of external envelopes could increase the problem of overheating during mid seasons and in office rooms during summer. Thus an idea of external shadowing devices was considered. But due to the fact that whole campus in under historic protection such modernization has to be agreed. It was stated that the façade of the building should be as simple as possible and any external elements cannot be visible.

The need of individual ventilation with external ducts, need of shading devices and restriction from historical protection office makes to consider double skin façade (at least on the south and west orientation). It occurs that such solution solve a problem with shading and gave possibility to hide external ventilation ducts. A double skin façade decreases outside noise. In order to ventilate space within double skin façade a low-speed fans were placed at the top of the façade.

The energy efficient lighting system with LED light sources and control system like occupancy sensor and zoning were used in order to decrease electricity consumption in the building.

In the Fig. 3 a scheme of double skin façade is presented.

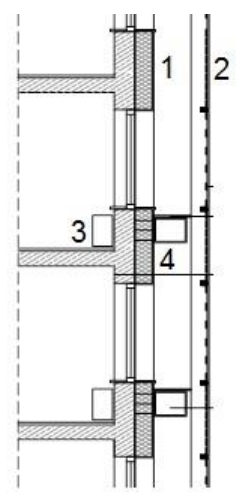

Fig. 3. A scheme of double skin façade (1-extra insulation, 2-PV panels, 3-individual ventilation units, 4-exhoust ventilation ducts).

All proposed systems were designed with the energy efficient auxiliary devices (pumps or fans) in order to not increase of electricity consumption in a significant way.

The analysis of energy sources was also done. It was concluded that due to the low value of the primary resource factor of the district heating any change of the heating source is groundless. Thus in order to decrease primary energy needs related with electricity 
consumption a photovoltaic installation was proposed. The PV panels were proposed to be installed on the roof and on the south and west façade, but only down to upper part of the surrounding trees.

However the low energy needs of the building do not result in comfortable spaces. Even if thermal comfort is maintained the aesthetics and friendless of the internal spaces is required. Thus some rearrangement of common spaces was proposed with extra social spaces and green plant introduction inside a building.

\subsection{Energy standard of retrofitted building}

In order to verify energy standard of a building with all proposed modernization an energy modelling has been repeated. All described measures were included in new building model. In the table 2 an energy characteristic of the building after retrofitting has been showed.

Table 2. The energy characteristic of the retrofitted building

\begin{tabular}{|c|c|}
\hline \multicolumn{2}{|c|}{ EP indicator [kWh/ $\mathbf{m} \mathbf{a}]$} \\
\hline Heating and ventilation & 8.9 \\
\hline Domestic hot water & 3.9 \\
\hline Cooling & 4.4 \\
\hline Lighting & 10.4 \\
\hline Auxiliary energy & 12.2 \\
\hline PV installation & -27.6 \\
\hline Sum & 12.2 \\
\hline
\end{tabular}

It can be noticed that primary energy needs decreased and total EP indicator is equal to $12.2 \mathrm{kWh} / \mathrm{m}^{2} \mathrm{a}$, what meets set goal of $20 \mathrm{kWh} / \mathrm{m}^{2} \mathrm{a}$.

The highest decrease can be noticed in heating and lighting consumption. The cooling needs increased what was connected with higher thermal resistance of building and an extra cooling system for all office spaces. It can be also noticed that energy production from PV installation was increased by 4.2 times. It must be stated that without electricity production from PV installation EP indicator would be equal to $39.8 \mathrm{kWh} / \mathrm{m}^{2} \mathrm{a}$. Thus it should be concluded that without renewable energy sources achieving nZEB standard in not possible.

\section{Conclusions}

It was shown that the use of IED process in building retrofitting project is possible and gives tangible benefits. Through common work of architects, constructor and HVAC engineers a chosen measures reflect in EP indicator decrease from $148.9 \mathrm{kWh} / \mathrm{m}^{2} \mathrm{a}$ for existing building to $12.2 \mathrm{kWh} / \mathrm{m}^{2}$ a for retrofitted building.

The planned actions include modernization of building elements (external walls, roofs, windows) as well as technical systems (HVAC, hot water, lighting and RES). Moreover, modernization concept includes some improvements in social use of the building e.g. new atrium with spaces for rest and group activities. Façades and planned atrium will be designed using "green architecture" concept.

\section{Acknowledgment}

This paper was performed with the financial support of EEA Financial Mechanism 20092014 - Operational Program PL04 "Saving energy and promoting renewable energy source" within the framework of the " project KODnZEB: "Thermo-modernization of two chosen Public Buildings according to nZEB Standards". 
Through the funds EEA and Norwegian funds, Iceland, Liechtenstein and Norway contribute to reducing social and economic inequality and strengthening bilateral relations with beneficiary countries in Europe. These three countries closely cooperate with the EC on the basis of the Agreement on the European Economic Area (EEA Agreement).

\section{References}

1. Directive 2010/31/EU of the European Parliament and of the Council of 19 May 2010 on the energy performance of buildings (OJ L 153, 18.06.2010)

2. Ordinance of the Minister of Transport, Construction and Maritime Economy of 5 July 2013 amending the regulation on technical conditions to be met by buildings and their location (Dz.U. 2013 pos. 926)

3. KODnZEB project, Thermo-modernization of two chosen Public Buildings according to nZEB Standards, Poland, (2016)

4. J. Kwiatkowski and J. Rucinska, The use of cost optimal methodology to determine nZEB standard of public building, 6th International Symposium on Energy Challenges \& Mechanics (ISECM) - towards a big picture, (14-18.08.2016, Inverness, Scotland)

5. http://www.designbuilder.co.uk/documents/DesignBuilder-flyer-v1a.pdf 